\title{
ANALISIS SPASIAL PRODUKTIVITAS SETENGAH PENGANGGUR DI INDONESIA TAHUN 2017: PERBANDINGAN DENGAN SEKTOR PRIMER
}

\author{
(Spatial Analysis of Underemployment Productivity in Indonesia 2017: \\ A Comparison with Primary Sector)
}

Kadek Aris Prasetya* dan Ernawati Pasaribu**

Politeknik Statistika STIS, Jl. Otto Iskandardinata No. 64 C, Jakarta Timur Email:*arisprasetya2@gmail.com,**ernapasaribu@stis.ac.id

Naskah diterima: 22 Agustus 2019

Naskah direvisi: 26 Agustus 2019

Naskah diterbitkan: 31 Desember 2019

\begin{abstract}
There are a large number of worker in Indonesia due to its high number of population. However, goverment should pay close attention to the worker's quality since it can cause problems in the economic structures integration. The quality of labor in each region can be measured by labor productivity. Labor productivity can be seen by underemployment rate, especially in primary sector. In analyzing underemployed workers, there is a possibility of inter-provincial linkages. This study aims to identify factors that affect productivity of underemployed workers, both direct and indirect effects and comparison with primary sector. The analytical method used is descriptive analysis and inferential analysis using spatial regression method. The results showed that the productivity of underemployed workers in all sectors and primary sector was affected by different spatial effects. Labor productivity of all sectors is influenced by spillover effect of independent variables, while in primary sector is influenced by spillover effect of independent variables and spatial effect of dependent variable. The productivity of workers in all sectors is more influenced by the level of education than the level of health, while in the primary sectors is more influenced by the level of health than the level of education. Wage and investment factors have a positive effect on all sectors and primary sector. This study recommends government to revitalize primary sector in order to integrate economic structure transformation and to improve quality of health, education, and investment to increase productivity.

Keywords: productivity, underemployment, SLX, SDM, spillover effect
\end{abstract}

\begin{abstract}
Abstrak
Indonesia adalah negara dengan jumlah penduduk yang tinggi, sehingga jumlah angkatan kerjanya juga tinggi. Namun apabila kualitas dari angkatan kerja tersebut rendah, maka hanya akan menimbulkan masalah dalam integrasi struktur ekonomi. Kualitas tenaga kerja daerah dapat diukur dengan nilai produktivitas pekerja. Salah satu faktor yang digunakan untuk melihat produktivitas pekerja adalah tingkat pekerja setengah menganggur khususnya pada sektor primer. Dalam menganalisis pekerja setengah menganggur terdapat kemungkinan adanya keterkaitan antarprovinsi. Penelitian ini bertujuan untuk mengidentifikasi faktor-faktor yang memengaruhi produktivitas pekerja setengah menganggur, baik efek langsung maupun tidak langsung serta perbandingannya dengan sektor primer. Metode analisis yang digunakan adalah analisis deskriptif serta analisis inferensial dengan metode regresi spasial. Hasil penelitian menunjukkan bahwa produktivitas pekerja setengah menganggur di seluruh sektor dan sektor primer dipengaruhi oleh efek spasial yang berbeda. Produktivitas pekerja seluruh sektor dipengaruhi oleh spillover effect dari variabel independen, sedangkan pada sektor primer dipengaruhi oleh spillover effect variabel independen dan efek spasial variabel dependen. Produktivitas pekerja di seluruh sektor lebih dipengaruhi oleh tingkat pendidikan dibandingkan tingkat kesehatan, sedangkan di sektor primer lebih dipengaruhi oleh tingkat kesehatan dibandingkan tingkat pendidikan. Tingkat upah dan tingkat investasi berpengaruh positif baik pada seluruh sektor maupun sektor primer. Penelitian ini merekomendasikan pemerintah untuk merevitalisasi sektor primer demi pengintegrasian perubahan struktur ekonomi serta meningkatkan kualitas kesehatan, pendidikan, dan investasi demi peningkatan produktivitas.

Kata kunci: produktivitas, setengah menganggur, SLX, SDM, efek tidak langsung
\end{abstract}

\section{PENDAHULUAN}

Indonesia merupakan negara kepulauan yang memiliki jumlah penduduk yang sangat besar. Dengan jumlah penduduk yang tinggi menjadikan Indonesia sebagai negara yang juga memiliki potensi jumlah tenaga kerja yang tinggi. Dilihat dari data Badan Pusat Statistik (BPS), tingkat pengangguran terbuka dari tahun 2010 hingga tahun 2017 cenderung mengalami penurunan, di mana pada Agustus 2017 mencapai 5,5 persen. Namun menurunnya tingkat pengangguran tersebut perlu ditinjau kembali dengan memerhatikan produktivitas yang dimiliki oleh angkatan kerja yang bekerja. Produktivitas pekerja adalah suatu ukuran yang dapat digunakan untuk melihat bagaimana kualitas tenaga kerja yang dimiliki suatu daerah. Meskipun tingkat pengangguran suatu daerah menurun, namun apabila produktivitas pekerja rendah maka akan menjadi masalah untuk daerah tersebut.

Menurut Cobb Douglas, tenaga kerja adalah salah satu faktor penting dalam pembangunan ekonomi. BPS mengatakan salah satu faktor yang dapat digunakan untuk melihat produktivitas tenaga kerja di Indonesia adalah melalui proporsi jumlah penduduk setengah menganggur yang bekerja di bawah 35 jam per minggu. Hal ini sesuai 
dengan konsep yang digunakan dalam penelitian Kinanti (2015) mengenai Analisis tentang Setengah Penganggur di Indonesia. Penelitian yang dilakukan oleh Kasmita (2014) mengatakan bahwa jam kerja memiliki pengaruh yang positif dan signifikan terhadap upah yang diterima. Hal ini penting untuk diperhatikan karena dengan demikian maka pekerja setengah menganggur memiliki kemungkinan besar berada pada kondisi dengan tingkat kesejahteraan yang rendah karena pendapatannya yang rendah. Namun pekerja tersebut termasuk sebagai angkatan kerja yang tidak tergolong dalam pengangguran, sehingga permasalahan ini tidak terlihat secara langsung. Pada penelitian ini unit analisis yang digunakan dibagi menjadi dua, yaitu pekerja setengah menganggur seluruh sektor dan juga secara spesifik pada sektor primer. Ketidakseimbangan transformasi struktur perekonomian yang terjadi di Indonesia diakibatkan karena lemahnya integrasi sektor primer ke sektor sekunder dan tersier. Hal ini ditunjukan dengan masih banyaknya komoditas barang ekspor Indonesia adalah barang mentah yaitu salah satunya ekspor kelapa sawit. Dengan demikian, penelitian ini ingin melihat bagaimana kondisi pekerja setengah menganggur pada seluruh sektor dibandingkan dengan khususnya sektor primer.

Berdasarkan data BPS (2017b) persebaran proporsi jumlah penduduk setengah menganggur menunjukkan bahwa adanya indikasi pengelompokkan produktivitas pekerja, di mana provinsi yang letaknya berdekatan memiliki nilai produktivitas yang mirip. Sehingga pada penelitian ini ingin dilihat bagaimana efek spasial produktivitas pekerja setengah menganggur di setiap provinsi di Indonesia. Efek spasial yang ingin dilihat tidak hanya efek secara langsung namun juga spillover effect atau efek tidak langsung terhadap produktivitas pekerja setengah menganggur di suatu daerah (Lesage \& Pace, 2009). Produktivitas pekerja yang diukur adalah produktivitas pekerja pada pekerja setengah menganggur. Sicat \& Arndt (1991) menjelaskan bahwa setengah pengangguran (underemployment) adalah situasi di mana para pekerja yang mempunyai pekerjaan tidak mencurahkan tenaganya untuk bekerja sepenuh waktu kerja. Menurut Anselin (1988) analisis mengenai karakteristik suatu wilayah akan dipengaruhi juga oleh karakteristik wilayah lainnya. Dengan kata lain perubahan suatu wilayah tidak hanya ditentukan secara langsung oleh beberapa faktor dari daerah tersebut namun juga dari karakteristik di daerah lainnya.

Penelitian mengenai produktivitas pekerja setengah menganggur dengan mempertimbangkan keterkaitan antarwilayah masih terbatas. Penelitianpenelitian yang telah ada sebelumnya hanya melihat produktivitas pada pekerja secara menyeluruh namun tidak spesifik pada pekerja tertentu. Seperti penelitian yang dilakukan oleh Priyanto (2014), yaitu melihat bagaimana dampak upah terhadap produktivitas pekerja. Penelitian serupa juga dilakukan oleh Faisal (2013), Ariani \& Suresmiathi (2013) serta Zulhanafi, et al. (2013) dengan salah satu tujuan penelitiannya, yaitu untuk mengetahui faktor-faktor yang memengaruhi produktivitas pekerja. Pekerja setengah menganggur penting untuk diperhatikan karena negara yang memiliki tingkat pekerja setengah menganggur yang tinggi berarti kualitas tenaga kerjanya rendah.

Penelitian mengenai produktivitas pekerja setengah menganggur di Indonesia menarik untuk dikaji lebih lanjut, karena cenderung memiliki peluang yang lebih tinggi dalam memiliki pendapatan yang rendah, terlebih dengan mengaitkannya terhadap perbedaan karakteristik yang terjadi antarprovinsi. Dengan mengetahui karakteristik pekerja setengah menganggur maka tingkat kesejahteraan pekerja tersebut akan dapat ditingkatkan melalui peningkatan produktivitasnya. Sektor primer adalah sektor ekonomi yang memanfaatkan sumber daya alam secara langsung. Kuznet \& Todaro (2000) menjelaskan bahwa sektor primer memiliki peranan yang penting dalam perkembangan perekonomian. Tujuan dari penelitian ini adalah untuk (1) memperoleh gambaran umum mengenai produktivitas pekerja setengah menganggur seluruh sektor dan sektor primer di masing-masing provinsi dan faktor-faktor yang memengaruhinya di Indonesia pada tahun 2017 dan (2) mengidentifikasi dan menganalisis efek spasial, baik efek langsung maupun efek tidak langsung, pada faktor-faktor yang memengaruhi produktivitas pekerja setengah menganggur seluruh sektor dan sektor primer di masing-masing provinsi Indonesia pada tahun 2017.

\section{METODE \\ Cakupan Penelitian}

Dalam penelitian ini unit analisis yang dicakup adalah seluruh provinsi di Indonesia, yaitu 34 provinsi dengan periode waktu penelitian tahun 2017. Pada tahun 2017 sudah dapat dirasakan bagaimana dampak dari bonus demografi dan pada saat pencarian data, penggunaan data terbaru adalah pada tahun 2017. Variabel yang digunakan terbagi menjadi dua, yaitu variabel independen dan dependen. Pemilihan variabel independen didasarkan pada beberapa teori dan penelitian terkait. Sukirno (2004) serta Pristyadi \& Sukaris (2017) menjelaskan bahwa salah satu faktor yang memengaruhi produktivitas pekerja adalah tingkat pendidikan. Sedangkan Todaro (2000) menjelaskan 
bahwa tingkat produktivitas dipengaruhi oleh tingkat kesehatan, belanja modal, dan tingkat upah yang dimiliki oleh seorang pekerja. Dengan demikian pada penelitian ini variabel independen yang digunakan terdiri dari upah minimum, tingkat pendidikan, tingkat kesehatan, dan investasi. Sedangkan variabel dependen adalah produktivitas pekerja setengah menganggur pada seluruh sektor dan sektor primer. Menurut BPS, pekerja setengah menganggur adalah pekerja yang memiliki jam kerja di bawah jam kerja normal atau di bawah 35 jam per minggu.

\section{Metode Pengumpulan Data}

Penelitian ini menggunakan data sekunder yang merupakan data cross-section pada seluruh provinsi di Indonesia pada tahun 2017. Data pada penelitian ini bersumber dari hasil pengolahan data Survei Angkatan Kerja Nasional (Sakernas) dan publikasi dari BPS. Variabel Upah Minimum Provinsi (UMP), ratarata lama sekolah (RLS), Angka Harapan Hidup (AHH), dan persentase belanja modal (PBM) diperoleh dari publikasi BPS. Sedangkan variabel produktivitas pekerja setengah menganggur seluruh sektor (Pr) dan sektor primer (Pr1) diperoleh dengan estimasi pada data Sakernas 2017. Estimasi produktivitas dilakukan dengan mengalikan nilai produktivitas masing-masing pekerja terhadap pembobot yang telah dibangun oleh BPS untuk estimasi pada level provinsi.

$$
\text { Produktivitas }_{j}=\frac{\sum_{i=1}^{n} W_{i j} \times P r_{i j}}{\sum_{i=1}^{n} W_{i j}}
$$

Di mana $W_{i j}$ adalah pembobot untuk estimasi pada level provinsi dan $\operatorname{Pr}_{i j}$ adalah produktivitas pekerja ke-i dan provinsi ke-j.

\section{Metode Analisis}

Dalam penelitian ini metode analisis dibagi menjadi dua bagian yaitu analisis deskriptif dan analisis inferensial. Analisis deskriptif dalam penelitian ini digunakan untuk menjawab tujuan pertama dalam penelitian yaitu dengan Exploratory Spatial Data Analysis (ESDA). Dalam analisis deskriptif, metode yang juga digunakan untuk menggambarkan produktivitas pekerja setengah menganggur di setiap provinsi yaitu dengan peta tematik yang dapat dibangun dengan ArcGIS 10.4 dan QGIS 3.4.5. Analisis deskriptif dalam menggambarkan produktivitas pekerja di setiap provinsi juga dapat dilihat melalui penyajian statistik Local Indicators of Spatial Association (LISA) dan Moran's Scatter Plot. Seperti penelitian yang dilakukan oleh Fatchurrohman (2014), digunakan statistik LISA untuk menggambarkan disparitas produktivitas. Dengan statistik LISA gambaran produktivitas setiap provinsi dapat ditunjukkan melalui beberapa klasifikasi yaitu high-high, high-low, low-high dan lowlow. Menurut Anselin (2005) high-high menunjukkan produktivitas pekerja yang tinggi pada suatu provinsi memiliki provinsi tetangga dengan produktivitas yang juga tinggi, sedangkan high-low merupakan klasifikasi yang menunjukkan bahwa provinsi dengan produktivitas pekerja yang tinggi namun memiliki provinsi tetangga dengan produktivitas pekerja yang rendah, low-high merupakan klasifikasi yang menunjukkan bahwa provinsi dengan produktivitas pekerja yang rendah namun memiliki provinsi tetangga dengan produktivitas pekerja yang rendah dan low-low merupakan klasifikasi yang menunjukkan bahwa provinsi dengan produktivitas pekerja yang rendah serta memiliki provinsi tetangga dengan produktivitas pekerja yang juga rendah. Pengujian efek spasial dilakukan dengan uji Global Moran's I pada variabel produktivitas pekerja setengah menganggur seluruh sektor dan sektor primer. Pembobot spasial yang digunakan adalah jarak geografis, seperti yang dijelaskan menurut Husni \& Wikarya (2014) bahwa perubahan tingkat produktivitas juga dipengaruhi oleh perpindahan pekerja. Demi memaksimalkan keuntungan dari adanya perpindahan pekerja maka pekerja akan melakukan perpindahan kerja menuju daerah yang terdekat atau memiliki jarak geografis yang rendah.

Pada analisis inferensial untuk mengetahui faktor-faktor yang memengaruhi produktivitas pekerja setengah menganggur dapat dilakukan dengan membangun Model Regresi Spasial dengan software R-Studio 3.4.0. Model Regresi Spasial yang dihasilkan dibedakan ke dalam model seluruh sektor dan sektor primer untuk dapat melihat perbandingan kondisi pada seluruh sektor dengan lebih spesifik pada sektor primer serta melihat efek langsung maupun efek tidak langsung dengan penimbang jarak geografis. Selain Spatial Durbin Model (SDM), Elhorst \& Vega (2017) menjelaskan bahwa Spatial Lag of $X$ (SLX) Model merupakan salah satu model yang dapat digunakan untuk menjelasakan spillover effect dari variabel independen dari wilayah tetangga. Spillever effect adalah pengaruh tidak langsung dari variabel independen daerah tetangga terhadap variabel dependen di suatu daerah. Adanya spillover effect menunjukkan bahwa produktivitas pekerja suatu daerah tidak hanya dipengaruhi oleh variabel independen daerah tersebut, namun juga dipengaruhi oleh variabel independen daerah lainnya. Dengan melihat efek spasial dari variabel dependen akan diketahui kondisi perkembangan ekonomi yang terjadi apakah backwash effect atau spread effect seperti salah satu kondisi ekonomi regional yang dibahas oleh Cappelo $(2007,2009)$ dalam Pasaribu 
(2015) mengenai spread effect dan backwash effect. Di mana spread effect merupakan dampak yang menguntungkan dari adanya pertumbuhan daerah inti atau daerah pusat. Hal ini diakibatkan karena pertumbuhan yang terjadi pada suatu daerah inti semakin lama akan menyebarkan sumber dayanya sehingga akan meningkatkan daerah di sekitarnya. Sedangkan backwash effect adalah suatu kondisi pertumbuhan daerah inti yang merugikan daerah yang berada di sekitarnya. Hal ini diakibatkan karena semakin lama pada saat pertumbuhan daerah inti atau daerah pusat meningkat, maka akan terjadi penyerapan sumber daya dari daerah yang berada di sekitarnya. Model Regresi Spasial yang digunakan dalam penelitian ini dengan pembobot $\mathrm{W}_{\mathrm{ij}}$, yaitu: Spatial Autoregressive with Disturbance Model

$$
\begin{aligned}
& \operatorname{Ln}\left(\operatorname{Pr} 1_{i}\right)=B_{0}+\rho \Sigma_{j=1, j \neq i}^{n} W_{i j} \ln \left(\operatorname{Pr} 1_{j}\right)+B_{1} \ln \left(U M P_{i}\right)+ \\
& B_{2} R L S_{i}+B_{3} A H H_{i}+B_{4} P B M_{i}+\lambda \Sigma_{j=1, j \neq i}^{n} W_{i j} u_{j}+
\end{aligned}
$$

Spatial Durbin Model (SDM)

$$
\begin{aligned}
\operatorname{Ln}\left(\operatorname{Pr} 1_{i}\right)= & B_{0}+\rho \Sigma^{n}{ }_{j=1, j \neq i} W_{i j} \ln \left(P r 1_{j}\right)+B_{1} \ln \left(U M P_{i}\right)+ \\
& \beta_{2} R L S_{i}+B_{3} A H H_{i}+B_{4} P B M_{i}+r_{1} \Sigma^{n}{ }_{j=1, j \neq i} \\
& W_{i j} \operatorname{In}\left(U M P_{j}\right)+r_{2} \Sigma^{n}{ }_{j=1, j \neq i} W_{i j} R L S_{j}+r_{3} \Sigma^{n}{ }_{j=1, j \neq i} \\
& W_{i j} A H H_{j}+r_{4} \sum^{n}{ }_{j=1, j \neq i} W_{i j} P B M_{j}+\varepsilon_{i} \ldots \ldots \ldots \ldots . .(3)
\end{aligned}
$$

Spatial Lag of $X$ Model (SLX)

$\operatorname{Ln}\left(\operatorname{Pr} 1_{i}\right)=B_{0}+B_{1} \ln \left(U M P_{i}\right)+B_{2} R L S_{i}+B_{3} A H H_{i}+B_{4} P B M_{i}+$

$r_{1} \sum_{j=1, j \neq i}^{n} W_{i j} \ln \left(U M P_{j}\right)+r_{2} \sum_{j=1, j \neq i}^{n} W_{i j} R L S_{j}+$

$r_{3} \sum^{n^{j}=1, j \neq i} W_{i j} A H H_{j}+r_{4} \sum^{n}{ }_{j=1, j \neq i} W_{i j} P B M_{j}+\varepsilon_{i} . .(4)$

Model Regresi Linear Berganda (RLB)

$$
\begin{aligned}
& \operatorname{Ln}\left(\mathrm{Pr}_{i}\right)=B_{0}+B_{1} \ln \left(U M P_{i}\right)+B_{2} R L S_{i}+B_{3} A H H_{i}+ \\
& B_{4} P B M_{i}+\varepsilon_{i}
\end{aligned}
$$

\section{HASIL DAN PEMBAHASAN}

\section{Gambaran Umum Produktivitas Pekerja Setengah Menganggur dan Faktor-Faktor yang Memengaruhinya Tingkat Pekerja Setengah Menganggur}

Persebaran tingkat pekerja setengah menganggur di masing-masing daerah menunjukkan kondisi tingkat produktivitas pekerja daerah tersebut. Persebaran tingkat pekerja setengah menganggur di seluruh provinsi di Indonesia dilihat dengan lima kelompok nilai menggunakan natural breaks yaitu sangat rendah, rendah, sedang, tinggi, dan sangat tinggi. Secara visual dapat dilihat bahwa persentase pekerja setengah menganggur yang memiliki nilai cenderung tinggi berada di Indonesia bagian timur. Sedangkan pada bagian baratnya, seperti Pulau Jawa dan Pulau Kalimantan, cenderung memiliki tingkat pekerja setengah menganggur yang rendah.

\section{Produktivitas Pekerja Setengah Menganggur}

Apabila dilihat secara umum, produktivitas

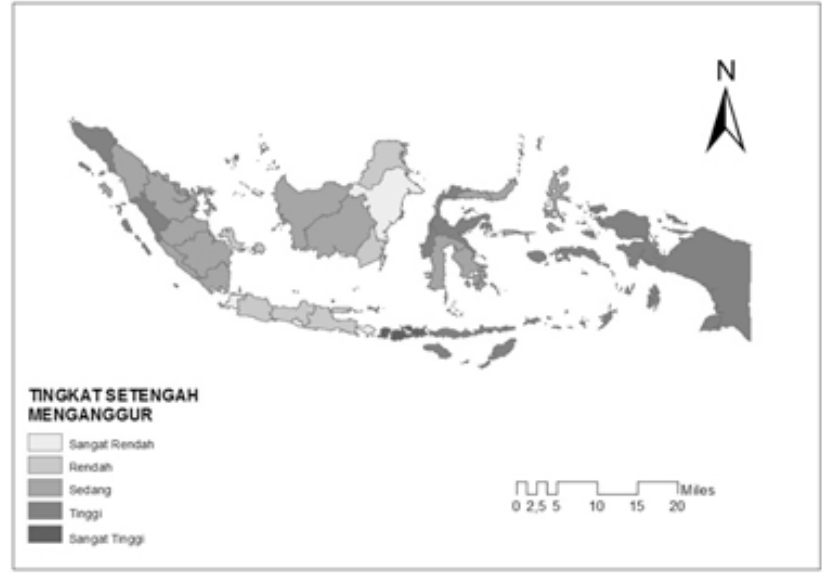

Sumber: BPS, 2017b.

Gambar 1. Peta Tematik Tingkat Pekerja Setengah Menganggur (dalam persen) Menurut Provinsi di Indonesia Tahun 2017

pekerja setengah menganggur pada seluruh sektor tidak terlalu menunjukkan adanya pola sebaran yang mengelompok. Dilihat pada Gambar 2a, semakin pekat warna hijau pada peta menunjukkan nilai produktivitas semakin tinggi. Ditunjukkan bahwa masih banyak provinsi yang memiliki nilai produktivitas pekerja yang rendah. Dari Gambar 2a tersebut dapat dilihat produktivitas pekerja setengah menganggur secara umum lebih didominasi di sebagian provinsi di Pulau Kalimantan serta Pulau Papua, sedangkan sebagian provinsi di Pulau Jawa hingga Nusa Tenggara memiliki nilai produktivitas yang cenderung rendah. Provinsi Jawa Tengah dan Jawa Timur sebagai daerah yang memiliki jarak geografis yang cukup berdekatan dengan DKI Jakarta ternyata memiliki nilai produktivitas yang sangat berbeda. Hal ini menunjukkan bahwa efek spasial dari produktivitas pekerja setengah menganggur tidak begitu kuat.

Sektor primer mendominasi pekerja setengah menganggur di Indonesia, namun apabila dilihat dari nilai produktivitas pekerja setengah menganggur di sektor primer masih tergolong cukup rendah dibandingkan produktivitas pekerja seluruh sektor. Rendahnya produktivitas pekerja di sektor primer akan menjadi masalah dalam transformasi struktural ekonomi. Transformasi struktural ekonomiakan berhasil apabila terjadi perpindahan ketergantungan dari sektor primer ke sektor sekunder dan sektor tersier, namun tanpa mengurangi kontribusi sektor primer terhadap Produk Domestik Bruto (PDB). Produktivitas pekerja setengah menganggur pada sektor primer apabila dilihat secara umum memiliki pola sebaran secara dominan pada Indonesia bagian barat. Dari gambar tersebut dapat dilihat produktivitas di sektor primer secara umum lebih tinggi di Pulau Sumatera dan Pulau Kalimantan sedangkan di daerah lainnya memiliki nilai produktivitas yang rendah. Hal ini menunjukkan bahwa 


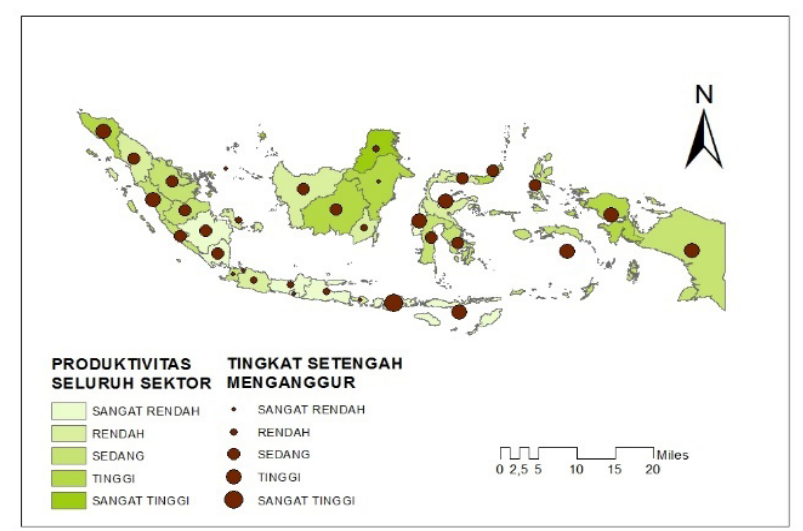

(a) Seluruh Sektor

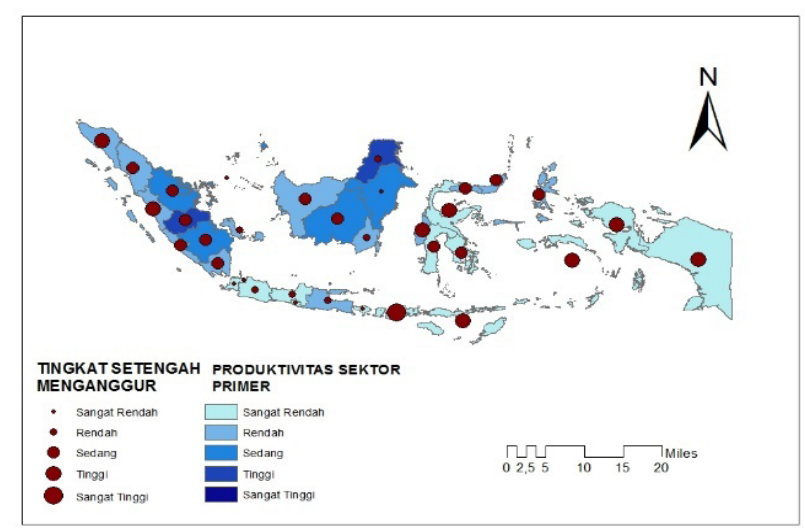

(b) Sektor Primer

Sumber: BPS, 2017b.

Gambar 2. Peta Tematik Overlay Produktivitas Pekerja Setengah Menganggur dan Tingkat Pekerja Setengah Menganggur

adanya indikasi pengelompokan pada produktivitas pekerja setengah menganggur di sektor primer.

\section{Upah Minimum Provinsi}

Pada Gambar 3a dapat dilihat bagaimana gambaran UMP serta kaitannya dengan produktivitas pekerja setengah menganggur sektor primer. Secara keseluruhan provinsi dengan produktivitas pekerja yang tinggi juga memiliki nilai UMP yang tinggi. Jika dilihat daerah yang memiliki nilai UMP yang rendah cenderung berada di Indonesia bagian tengah namun hanya daerah selatan, seperti Pulau Jawa hingga NTT, kecuali Jakarta, Banten, dan Bali. Hubungan yang positif antara produktivitas pekerja setengah menganggur di sektor primer dengan nilai UMP ditunjukkan melalui dominasi warna campuran, baik gelap maupun agak terang, yang terlihat pada kotak diagonal. Penggambaran yang dominan hampir sama dan sebanding antara nilai UMP dan nilai produktivitas pekerja setengah menganggur sektor primer memberikan indikasi bahwa adanya hubungan positif antara nilai UMP dan produktivitas pekerja setengah menganggur sektor primer.

\section{Persentase Belanja Modal}

Dari peta choroplet pada Gambar 3b dapat dilihat secara keseluruhan persentase belanja modal yang tinggi berada pada daerah dengan produktivitas pekerja setengah menganggur sektor primer yang juga tinggi, meskipun terdapat juga beberapa provinsi yang sebaliknya. Sehingga memberikan indikasi bahwa adanya hubungan positif antara nilai persentase belanja modal dengan nilai produktivitas. Persebaran nilai persentase belanja modal yang tergolong tinggi mengelompok pada Provinsi Sumatera Selatan, Riau, Kepulauan Riau, dan Bengkulu, sedangkan nilai persentase belanja modal yang rendah didominasi di sebagian besar provinsi di Pulau Jawa, sebagian di
Pulau Sumatera, dan NTT. Persentase belanja modal yang tinggi memberikan indikasi bahwa daerah tersebut merupakan daerah yang masih berada pada masa pembangunan, sehingga infrastruktur dan investasi ditingkatkan dalam membangun daerah demi meningkatkan perkembangan ekonomi.

\section{Rata-rata Lama Sekolah}

Dalam Gambar 3c melalui peta choroplet ditunjukkan bagaimana persebaran nilai rata-rata lama sekolah dan produktivitas pekerja di sektor primer. Persebaran sebagian nilai RLS memiliki arah yang sama dengan produktivitas pekeja setengah menganggur sektor primer namun sebagian juga memiliki arah yang berbeda. Apabila dilihat pada Pulau Kalimantan dan Pulau Sumatera didominasi oleh provinsi dengan nilai RLS yang tinggi. Sedangkan daerah Nusa Tenggara dan sebagian Pulau Jawa didominasi oleh Provinsi dengan nilai RLS yang rendah. Dari gambar dapat dilihat nilai RLS di sebagian provinsi di Jawa seperti Jawa Tengah dan Jawa Timur tergolong rendah. Nilai RLS yang rendah di provinsi tersebut menunjukkan bahwa tingginya jumlah penduduk tidak setara dengan kondisi pendidikan di daerah tersebut.

\section{Angka Harapan Hidup}

Persebaran angka harapan hidup yang ditunjukkan pada Gambar 3d memberikan indikasi hubungan yang positif dengan produktivitas pekerja setengah menganggur pada sektor primer. Provinsi dengan produktivitas pekerja yang tinggi memiliki nilai angka harapan hidup yang juga tinggi. Demikian juga provinsi dengan produktivitas pekerja yang rendah memiliki nilai angka harapan hidup yang juga rendah seperti yang ditunjukkan di Indonesia bagian tengah seperti NTB hingga Indonesia bagian timur seperti NTT, Maluku hingga Papua. Rendahnya nilai AHH di Indonesia bagian 
(a)

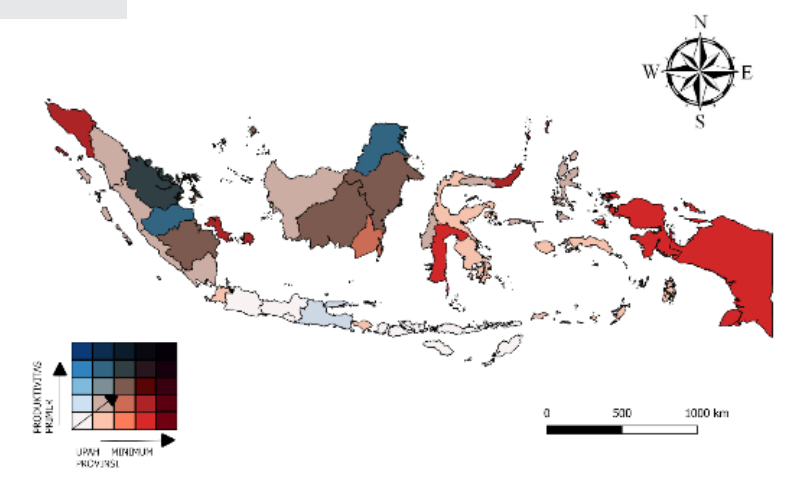

(c)

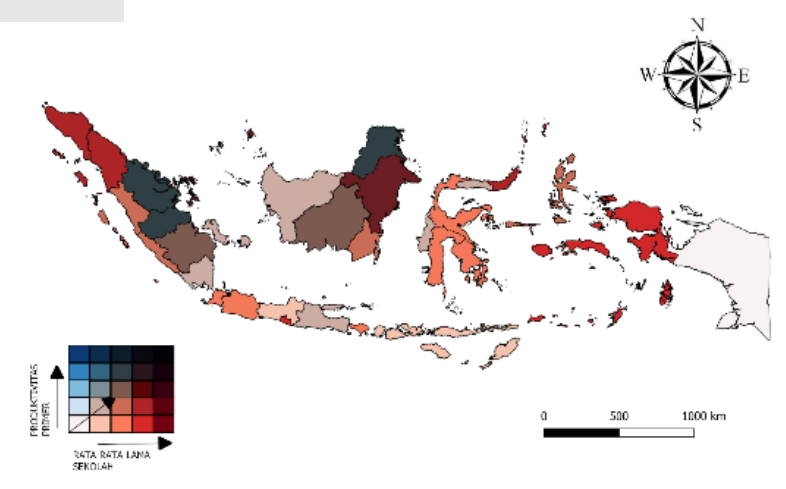

(b)

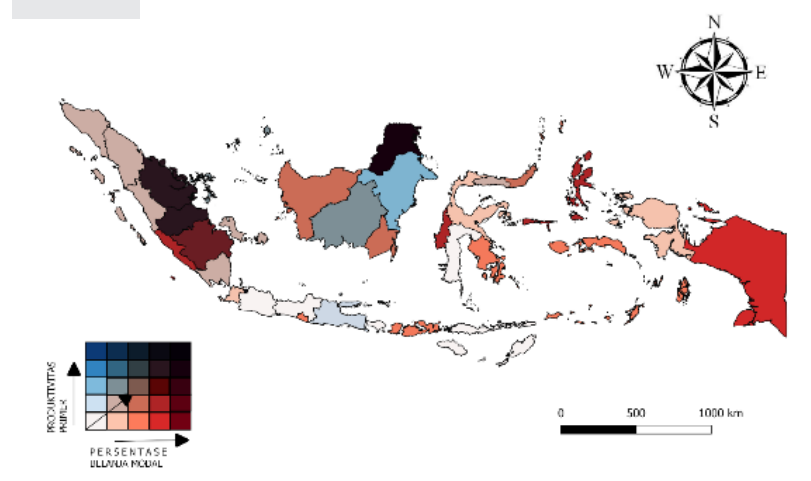

(d)

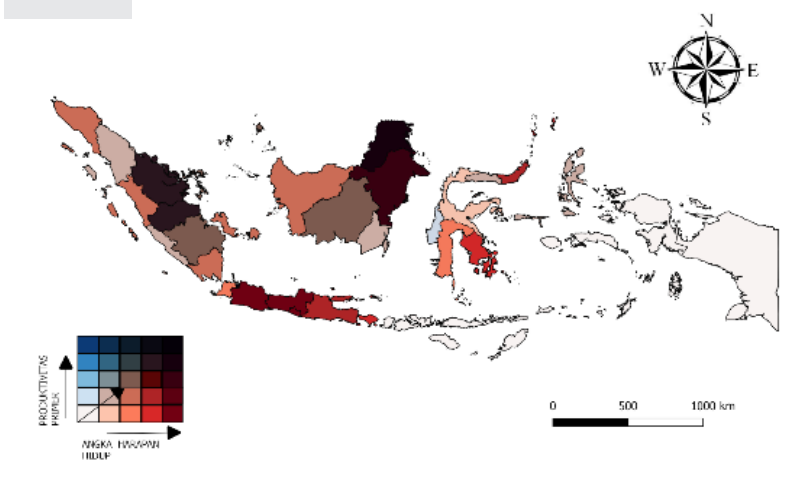

Sumber: BPS; 2017a, 2017b, 2017c.

Gambar 3. Peta Tematik Keterkaitan Produktivitas Pekerja Setengah Menganggur Sektor Primer dengan (a) UMP,

(b) Persentase Belanja Modal, (c) RLS, dan (d) $\mathrm{AHH}$

timur juga diakibatkan oleh masih lemahnya aksesibilitas daerah tersebut sehingga proses pembangunan fasilitas kesehatan tidak dapat dilakukan dengan cepat.

\section{Analisis Eksplorasi Spasial Produktivitas Pekerja Setengah Menganggur \\ Global Moran's I}

Hasil uji global moran's I pada variabel produktivitas pekerja setengah menganggur seluruh sektor menghasilkan keputusan gagal tolak $\mathrm{H}_{0^{\prime}}$ sedangkan pada sektor primer menghasilkan tolak $\mathrm{H}_{0}$. Hal ini menunjukkan terdapat autokorelasi spasial pada variabel produktivitas pekerja setengah menganggur di sektor primer, sedangkan pada produktivitas seluruh sektor tidak terdapat autokorelasi spasial. Nilai global moran's / baik pada seluruh sektor maupun sektor primer memiliki nilai positif di mana untuk sektor primer bernilai 0,091. Nilai Global Moran's I yang positif pada sektor primer berarti provinsi dengan produktivitas yang mirip di masing-masing sektor cenderung mengalami pengelompokkan yang digambarkan berdasarkan pembobot $W$-Geographic yang merupakan pombobot jarak geografis.

\section{Moran Scatterplot dan Local Indicators of Spatial Association (LISA) Sektor Primer}

Sebaran nilai produktivitas pekerja setengah menganggur sektor primer didominasi oleh kuadran I dan kuadran III. Kuadran I dan kuadran III memiliki jumlah provinsi yang berbeda di mana kuadran I atau (high-high) sebanyak 11 dan kuadran III atau (low-low) sebanyak 14. Sedangkan kuadran II dan IV berjumlah 9 provinsi, di mana untuk kuadran II atau (low-high) sebanyak 1 provinsi sedangkan kuadran IV atau (highlow) sebanyak 8 provinsi. Berdasarkan Gambar 5b dapat dilihat bagaimana pengelompokkan produktivitas pekerja setengah meganggur di sektor primer. Dari 34 provinsi terdapat 7 provinsi yang signifikan memiliki karakteristik pengelompokkan tertentu, yaitu 4 provinsi yang terkategori sebagai "high-high" dan 3 provinsi yang tergolong sebagai "low-low". Provinsi dengan kategori "high-high", yaitu Riau, Jambi, Sumatera Selatan, dan Kepulauan Riau. Sedangkan provinsi yang tergolong "low-low" yaitu NTB, NTT, dan Maluku.

\section{Faktor-Faktor yang Memengaruhi Produktivitas Pekerja Setengah Menganggur di Indonesia \\ Berdasarkan pengujian statistik Global Morans'I tidak ditemukannya efek spasial pada produktivitas}




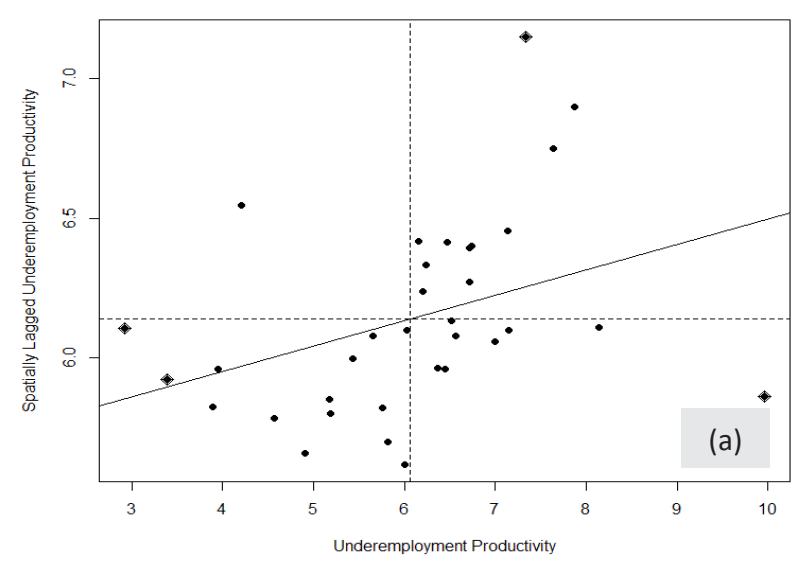

(a) Moran's Scatterplot

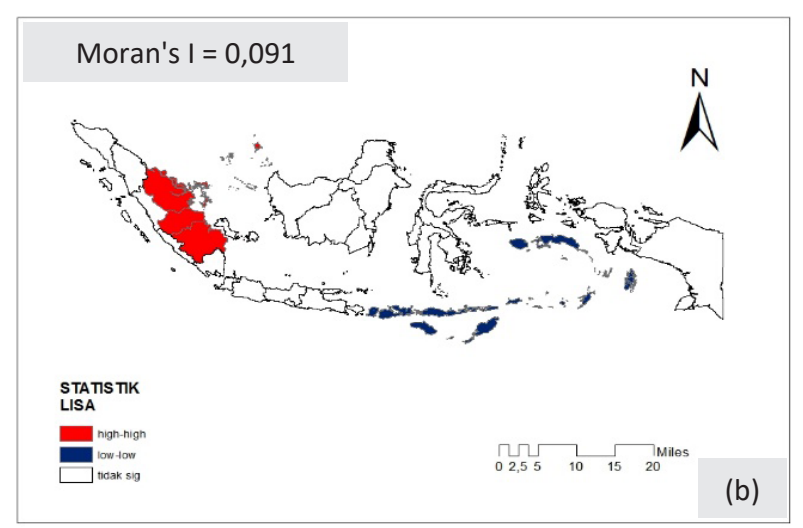

(b) Peta indikator Local Indicators Spatial Association

Sumber: BPS, 2017.

Gambar 4. Exploratory Spatial Data Analysis Produktivitas Pekerja Setengah Menganggur Sektor Primer

pekerja setengah menganggur sehingga efek spasial yang dipertimbangkan adalah pada variabel independen. Hasil estimasi parameter Model Regresi Spasial produktivitas pekerja setengah menganggur seluruh sektor dapat dilihat pada Tabel 1.

Pemilihan model terbaik yang menggambarkan faktor-faktor yang memengaruhi produktivitas pekerja setengah menganggur untuk seluruh sektor dapat dilihat dengan membandingkan nilai $\mathrm{R}^{2}$, AIC, BIC, serta pengujian statistik Log-likelihood (Lampiran 1). Perbandingan antara kedua model tersebut, yaitu:

Perbandingan nilai pada Tabel 2 tersebut menunjukkan bahwa Model SLX memiliki nilai AIC terendah serta nilai $\mathrm{R}^{2}$ tertinggi serta uji likelihood ratio signifikan (Lampiran 1 ), meskipun nilai BIC-nya lebih tinggi, sehingga berdasarkan perbandingan nilai tersebut SLX adalah Model Regresi Spasial terbaik yang digunakan untuk dapat menggambarkan variabel-variabel yang memengaruhi produktivitas pekerja setengah menganggur seluruh sektor. Dari hasil pengujian homokedastisitas, normalitas dan non-autokorelasi dapat dilihat nilai $p$-value lebih

Tabel 1. Koefisien Estimasi Parameter Model Regresi Spasial (Seluruh Sektor)

\begin{tabular}{lcc}
\hline \multicolumn{1}{c}{ Variabel } & RLB & SLX \\
\hline \multicolumn{1}{c}{$(1)$} & $(2)$ & $(3)$ \\
\hline Intercept & $-8,491$ & $-9,340$ \\
Logaritma natural UMP & $0,953^{* * *}$ & $0,659^{* *}$ \\
Rata-rata lama sekolah & $0,203^{* * *}$ & $0,146^{* *}$ \\
Angka harapan hidup & 0,018 & 0,035 \\
Persentase belanja modal & 0,011 & $0,019^{*}$ \\
W $\times$ Logaritma natural UMP & - & 0,555 \\
W $\times$ Rata-rata lama sekolah & - & $-0,571$ \\
W $\times$ Angka harapan hidup & - & $-0,014$ \\
W $\times$ Persentase belanja modal & - & $0,125^{*}$ \\
\hline
\end{tabular}

Keterangan: $*, * *, * * *$ masing-masing signifikan pada alpha 10 persen, 5 persen, dan 1 persen.

Sumber: Hasil Olah Data.
Tabel 2. Statistik Perbandingan Model Regresi Spasial (Seluruh Sektor)

\begin{tabular}{cccc}
\hline Uji & AIC & BIC & $\mathbf{R}^{2}$ \\
\hline (1) & $(2)$ & $(3)$ & $(4)$ \\
\hline RLB & 12,032 & 21,190 & 0,610 \\
\hline SLX & 11,696 & 26,959 & 0,646 \\
\hline
\end{tabular}

Sumber: Hasil Olah Data.

besar dari tingkat signifikansi 5 persen, sehingga asumsi normalitas, homokedastisitas, dan nonautokorelasi terpenuhi (Lampiran 1). Sedangkan untuk asumsi non-multikolinearitas, berdasarkan nilai Variance Inflation Factor (VIF) pada setiap variabel tidak ada yang memiliki nilai lebih dari 10 (Lampiran 2) sehingga asumsi non-multikolinearitas juga terpenuhi.

Dengan demikian untuk produktivitas pekerja setengah menganggur dengan Model SLX, persamaannya dapat dituliskan sebagai berikut:

$$
\begin{aligned}
\operatorname{Ln}\left(\operatorname{Pr}_{i}\right)= & -9,34+0,659 \ln \left(U M P_{i}\right)^{*}+0,146 R L S_{i}^{*}+ \\
& 0,0035 A H H_{i}+0,019 P B M_{i}^{*}+0,555 \sum^{n}{ }_{j=1,} \\
& W_{j \neq i} \ln \left(U M P_{j}\right)-0,571 \sum^{n}{ }_{j=1, j \neq i} W_{i j} R L S_{j}-0,014 \\
& \sum_{j=1, j \neq i}^{n} W_{i j} A H H_{j}+0,125 \sum_{j=1, j \neq i}^{n} W_{i j} P B M_{j}^{*} \text { (6) }
\end{aligned}
$$

Sedangkan Model SLX yang dipengaruhi oleh tiga provinsi dengan efek spasial terbesar, yaitu sebagai berikut:

$$
\begin{aligned}
& \operatorname{Ln}\left(\operatorname{Pr}_{\text {JAMB }}\right)= \\
& -9,34+0,659 \ln \left(\text { UMP }_{\text {JAMBB }}\right)^{*}+0,146 R L_{\text {JAMBI }}{ }^{*}+ \\
& 0,0035 \mathrm{AHH}_{\text {JAMBI }}+0,019 P B L_{\text {JAMBI }}{ }^{*}+ \\
& 0,251 \ln \left(U M P_{\text {KEPRIAU }}\right)+0,079 \ln \left(U M P_{\text {RIAU }}\right)+ \\
& 0,023 \text { In (UMP SUMATERA SELATAN }) \text { - } \\
& 0,258 R L S_{\text {KEP RIAU }}-0,081 R L S_{\text {RIAU }} \\
& 0,024 R L S_{\text {SUMATERA SELATAN }}-0,0063 A_{\text {KEP }} \\
& \text { RIAU }-0,0019 A H_{\text {RIAU }}^{-} \\
& \begin{array}{lcl}
0,00059 \mathrm{AHH}_{\text {SUMATERA }} & \text { SELATAN } \\
0,057 P B M & * \\
* & + & 0,018 P B M
\end{array}{ }^{+} \\
& 0,057 P B M_{\text {KEP RIAU }}{ }^{*}+0,018 P B M_{\text {RIAU }}{ }^{*}+ \\
& 0,0053 P B M_{\text {SUMATERA SELATAN }}
\end{aligned}
$$


Variabel UMP memiliki pengaruh yang positif terhadap produktivitas pekerja setengah menganggur. Kenaikan UMP di suatu daerah cenderung akan meningkatkan produktivitas pekerja di daerah tersebut. Pengaruh signifikan dan positif dari upah ini sesuai dengan teori yang dikemukakan oleh Todaro (2000) di mana salah satu penyebab dari rendahnya produktivitas pekerja adalah rendahnya upah dari pekerja tersebut. Hasil ini juga sesuai dengan penelitian yang dilakukan oleh Priyanto (2014) di mana variabel upah pekerja memiliki pengaruh yang signifikan dan positif terhadap produktivitas pekerja. Dampak positif upah terhadap produktivitas pekerja yang disampaikan Priyanto tersebut ternyata juga signifikan berpengaruh pada pekerja setengah menganggur yang memiliki jam kerja di bawah 35 jam per minggu. Demikian juga penelitian yang dilakukan oleh Azhara (2014) yang menunjukkan bahwa upah adalah salah satu variabel yang signifikan memengaruhi produktivitas pekerja. Dalam suatu teori ekonomi, menurut Borjas (2013) ada dua efek yang ditimbulkan pada saat terjadi kenaikan upah, yaitu efek pendapatan dan efek substitusi. Efek pendapatan menunjukan bahwa kenaikan upah akan menurunkan jam kerja, sedangkan efek substistusi menunjukkan bahwa kenaikan upah akan meningkatkan jam kerja. Pada kondisi ini terjadinya kenaikan upah minimum akan cenderung didominasi oleh efek pendapatan, di mana pekerja akan minimal tidak merubah jam kerjanya. Dengan demikian peningkatan upah yang dipengaruhi oleh peningkatan UMP akan meningkatkan produktivitas pekerja setengah menganggur.

Pada sisi pembangunan modal manusia (human capital), yaitu tingkat pendidikan di suatu daerah digambarkan melalui rata-rata lama sekolah. Variabel RLS memiliki pengaruh yang positif dan signifikan pada produktivitas pekerja setengah menganggur. Hal ini sesuai dengan teori dari Sukirno (2004) serta Pristyadi \& Sukaris (2017) yang mengatakan bahwa produktivitas pekerja dipengaruhi oleh pengetahuan yang dimiliki oleh pekerja itu sendiri. Tingkat pendidikan yang memiliki pengaruh positif ini juga sesuai dengan penelitian yang dilakukan oleh Zulhanafi, et al. (2013). Sedangkan penelitian yang dilakukan oleh Fitri, et al. (2015) menggunakan pendekatan realisasi investasi pendidikan untuk menggambarkan tingkat pendidikan itu sendiri. Hasil dari penelitian tersebut menunjukkan bahwa tingkat pendidikan memiliki pengaruh yang positif terhadap produktivitas pekerja. Hal ini diakibatkan karena pada produktivitas pekerja setengah mengangur seluruh sektor yang juga terdapat sektor sekunder dan tersier biasanya memerlukan dan memerhatikan latar belakang pendidikan dalam bekerja yang digunakan untuk melihat bagaimana kualitas pekerjanya. Pengaruh secara tidak langsung (spillover effect) dari rata-rata lama sekolah terhadap produktivitas pekerja tidak berpengaruh signifikan pada seluruh sektor. Tidak signifikannya spilover effect RLS pada produktivitas pekerja seluruh sektor menunjukkan bahwa pengaruh pendidikan yang kuat hingga berdampak pada daerah lainnya mungkin terjadi pada pekerja full employment atau pekerja dengan jam kerja normal, di mana migrasi pekerja yang terjadi memiliki kualifikasi pendidikan yang tinggi.

Salah satu variabel penting dari sisi tenaga kerja adalah tingkat kesehatan. Variabel kesehatan yang digunakan dalam penelitian ini adalah angka harapan hidup. Berdasarkan Model SLX yang telah dibentuk ternyata angka harapan hidup memiliki pengaruh yang positif namun tidak signifikan terhadap produktivitas pekerja setengah menganggur di seluruh sektor. Tidak signifikannya pengaruh dari angka harapan hidup terhadap produktivitas pekerja setengah menganggur bukan berarti bahwa tingkat kesehatan dapat diabaikan. Pengaruh yang positif menunjukkan bahwa semakin tinggi tingkat kesehatan maka produktivitas pekerjanya juga akan semakin meningkat. Dengan demikian tingkat kesehatan tidak dapat diabaikan karena menurut Todaro (2000) dikatakan bahwa produktivitas pekerja yang rendah di negara berkembang diakibatkan karena rendahnya tingkat kesehatan pekerja. Demikian juga efek tidak langsung dari angka harapan hidup tidak berpengaruh secara signifikan. Dengan demikian tingkat kesehatan daerah tetangga tidak berpengaruh terhadap produktivitas pekerja di suatu daerah.

Persentase belanja modal menunjukan seberapa besar belanja modal yang dikeluarkan pemerintah dibandingkan total pengeluaran yang dibelanjakan pada tahun tertentu. Persentase belanja modal pada model persamaan yang telah dibangun menunjukkan peranan yang cukup penting. Hal ini ditunjukkan dengan pengaruh persentase belanja modal yang positif dan signifikan terhadap produktivitas pekerja setengah menganggur di seluruh sektor. Semakin tinggi persentase belanja modal atau semakin tinggi belanja modal yang dilakukan pemerintah dalam rangka pembangunan negara maka produktivitas pekerja setengah menganggur juga akan semakin meningkat. Demikian juga seperti yang disampaikan Todaro (2000) dalam teorinya mengenai "diminishing marginal productivity" mengungkapkan bahwa penurunan produktivitas pekerja dilihat dari faktor produksi di mana rendahnya produktivitas disebabkan oleh modal yang rendah. Sesuai dengan penelitian yang dilakukan oleh Ariani \& Suresmiathi 
Tabel 3. Hasil Pengujian Efek Spasial

\begin{tabular}{lccc}
\hline & Uji & Nilai Statistik Uji & P-Value \\
\hline (1) & $(2)$ & $(3)$ \\
\hline LM-Lag & 0,305 & 0,581 \\
\hline LM-Error & 0,547 & 0,459 \\
\hline RLM-Lag & 5,602 & $0,018^{* *}$ \\
\hline RLM-Error & 5,844 & $0,016^{* *}$ \\
\hline
\end{tabular}

Keterangan: $*, * *, * * *$ masing-masing signifikan pada alpha 10 persen, 5 persen, dan 1 persen.

Sumber : Hasil Olah Data.

(2013) di mana hasil penelitiannya menunjukkan bahwa bantuan modal serta teknologi memiliki peran penting dalam meningkatkan produktivitas pekerja. Sedangkan penelitian yang dilakukan oleh Sitorus \& Yuliana (2018) dengan melihat infrastruktur sebagai variabel investasi, menyatakan bahwa infrastruktur memiliki pengaruh yang signifikan terhadap produktivitas suatu daerah. Apabila dilihat dari efek tidak langsung (spillover effect) maka dapat dilihat persentase belanja modal memiliki pengaruh yang signifikan. Hal ini menunjukkan bahwa peningkatan persentase belanja modal di daerah tetangga akan meningkatkan produktivitas pekerja suatu daerah.

Faktor-Faktor yang Memengaruhi Produktivitas Pekerja Setengah Menganggur Sektor Primer

Dengan pembobot jarak, produktivitas pekerja setengah menganggur di sektor primer secara signifikan memiliki efek spasial. Dengan demikian untuk mengetahui faktor-faktor yang memengaruhi produktivitas pekerja setengah menganggur di sektor primer, digunakan metode analisis regresi spasial. Dengan demikian diperlukan pengujian Model Spasial menggunakan uji Lagrange Multiplier (LM) dan Robust Lagrange Multiplier (RLM) pada spatial-lag, spatial-error, atau keduanya (Spatial Autoregressive Moving Average atau SARMA). Hasil
Tabel 5. Statistik Perbandingan Model Regresi Spasial (Sektor Primer)

\begin{tabular}{lccc}
\hline \multicolumn{1}{c}{ Uji } & AIC & BIC & $\mathbf{R}^{2}$ \\
\hline \multicolumn{1}{c}{$(1)$} & $(2)$ & $(3)$ & $(4)$ \\
\hline SARAR & 111,340 & 123,553 & 0,516 \\
\hline SDM & 101,180 & 117,971 & 0,699 \\
\hline SLX & 107,515 & 122,779 & 0,615 \\
\hline \multicolumn{2}{l}{ Sumber: Hasil Olah Data. } & &
\end{tabular}

pengujian model spasial tersebut disajikan pada Tabel 3.

Berdasarkan hasil pengujian spasial pada Tabel 3 dapat dilihat bahwa pengujian dengan Robust Lagrange Multiplier (RLM) menghasilkan keputusan tolak $\mathrm{H}_{0}$ dengan tingkat signifikansi 5 persen baik pada RLM-lag maupun pada RLM-error. Selain kedua pengujian tersebut, hasil uji untuk SARMA juga menunjukkan hasil keputusan tolak $\mathrm{H}_{0}$ yang berarti baik spatial-lag maupun spatial-error secara signifikan memiliki pengaruh spasial. Dengan demikian indikasi model yang tepat digunakan untuk mengadopsi efek spasial adalah SARMA, SDM, dan SLX. Hasil estimasi parameter Model Regresi Spasial produktivitas pekerja setengah menganggur sektor primer dapat dilihat pada Tabel 4.

Pemilihan model terbaik yang menggambarkan faktor-faktor yang memengaruhi produktivitas pekerja setengah menganggur sektor primer dapat dilihat dengan membandingkan nilai $\mathrm{R}^{2}, \mathrm{AIC}, \mathrm{BIC}$, serta pengujian statistik Log likelihood (Lampiran 1). Perbandingannya, yaitu:

Perbandingan nilai pada Tabel 5 tersebut menunjukkan bahwa SDM memiliki nilai AIC dan BIC terendah sedangkan nilai $\mathrm{R}^{2}$ nya tertinggi, sehingga berdasarkan perbandingan nilai tersebut SDM adalah model regresi spasial terbaik yang digunakan untuk dapat menggambarkan variabel-variabel yang memengaruhi

Tabel 4. Koefisien Estimasi Parameter Model Regresi Spasial (Sektor Primer)

\begin{tabular}{|c|c|c|c|}
\hline Variabel & SARMA & SDM & SLX \\
\hline (1) & (2) & (3) & (4) \\
\hline Intercept & $-67,358$ & $-470,174$ & $-355,496$ \\
\hline$W \times$ logaritma natural produktivitas (Sektor Primer) & $0,735 * * *$ & $-1,749 * * *$ & - \\
\hline Logaritma natural UMP & $3,648 * * *$ & $3,514 * * *$ & $3,408 * * *$ \\
\hline Rata-rata lama sekolah & 0,197 & 0,246 & 0,155 \\
\hline Angka harapan hidup & $0,189 * * *$ & $0,207 * * *$ & $0,176^{*}$ \\
\hline Persentase belanja modal & $0,060 * *$ & $0,057 * *$ & 0,035 \\
\hline$W \times$ Error & $-1,694 * * *$ & - & - \\
\hline$W \times$ Logaritma natural UMP & - & $21,961 * * *$ & 16,857 \\
\hline$W \times$ Rata-rata lama sekolah & - & 0,067 & $-0,387$ \\
\hline$W \times$ Angka harapan hidup & - & $1,305 * * *$ & $0,776^{*}$ \\
\hline$W \times$ Persentase belanja modal & - & $0,465 * * *$ & 0,148 \\
\hline
\end{tabular}

Keterangan: $*, * *, * *$ masing-masing signifikan pada alpha 10 persen, 5 persen, dan 1 persen

Sumber: Hasil Olah Data. 


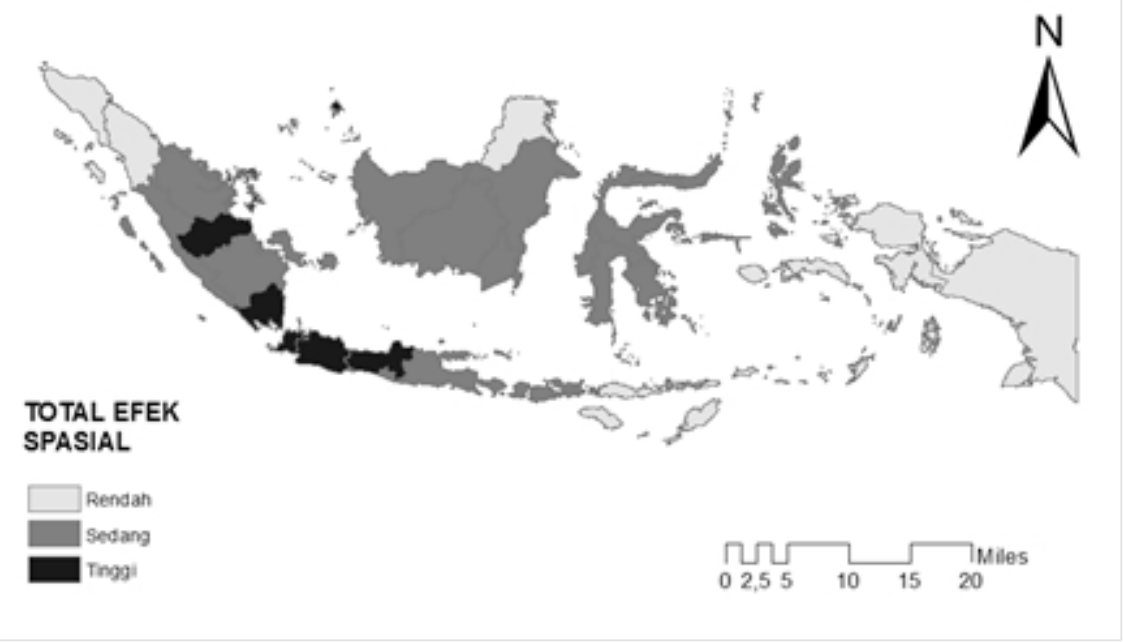

Sumber: Anselin, 2005.

Gambar 5. Peta Tematik Total Efek Spasial Produktivitas Pekerja Setengah Menganggur Sektor Primer Menurut Provinsi di Indonesia Tahun 2017

produktivitas pekerja setengah menganggur pada sektor primer. Dari hasil pengujian homokedastisitas serta normalitas dapat dilihat nilai $p$-value lebih besar dari tingkat signifikansi 5 persen, sehingga asumsi normalitas dan homokedastisitas terpenuhi (Lampiran 1). Sedangkan untuk asumsi non-multikolinearitas, berdasarkan nilai VIF pada setiap variabel tidak ada yang memiliki nilai lebih dari 10 (Lampiran 2) sehingga asumsi non-multikolinearitas terpenuhi.

Dengan demikian untuk produktivitas pekerja setengah menganggur sektor primer dengan Model SDM persamaannya dapat dituliskan sebagai berikut: $\operatorname{Ln}\left(\operatorname{Pr} 1_{i}\right)=-470,174 P-1,749 \Sigma_{j=1, j \neq i}^{n} W_{i j} \ln \left(\operatorname{Pr} 1_{j}\right)^{*}+$ $3,514 \ln \left(U M P_{j}\right)^{*}+0,246 R L S_{i}+0,207 A H H_{i}^{*}+$ $0,057 P B L_{i}^{*}+21,916 \Sigma^{n}{ }_{i=1 ; j i} W_{i j} \ln \left(U M P_{j}\right)^{*}+$ $0,067 \Sigma_{j=1, j \neq i}^{n} W_{i j} R L S_{j}+1,305 \Sigma_{j=1, j \neq i}^{n} W_{i j} A H H_{j}^{*}+$ $0,465 \Sigma^{n}{ }_{j=1, j \neq i} W_{i j} P B M_{j}$

Sedangkan contoh model dengan efek spasial dari tiga provinsi terbesar dapat dilihat pada model berikut:

$$
\begin{aligned}
& \begin{aligned}
\operatorname{Ln}\left(\operatorname{Pr} 1_{\text {JAMBI }}\right)= & -470,174-0,791 \ln (P R 1)_{\text {KeP RIAU }}{ }^{*}{ }^{*}, 217 \ln (P R 1)_{\text {RAUU }}{ }^{*}-0,073 \ln (P R 1)_{\text {SUMATEASEATAN }}{ }^{*}+
\end{aligned} \\
& 3,514 \ln \left(U M P_{\text {JAMBB }}\right)^{*}+0,246 R L S_{\text {JAMB }}+
\end{aligned}
$$

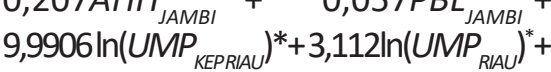

$$
\begin{aligned}
& 0,92 \ln \left(U M P_{\text {SUMATERA }}^{\text {KEPRAUA }}\right)^{*}+ \\
& 0,03 R L S_{\text {KEPRIAU }}+0,0083 R L S_{\text {RIAU }}+
\end{aligned}
$$

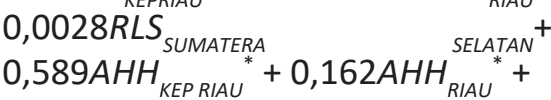

$$
\begin{aligned}
& 0,031 \text { AHH }_{\text {SEM RIAU }}{ }^{\text {RIAU }}+
\end{aligned}
$$

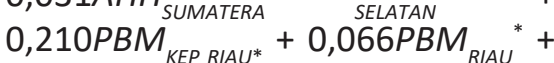

$$
\begin{aligned}
& \text { 0,019PBM }
\end{aligned}
$$

Total efek spasial dari variabel produktivitas pekerja setengah menganggur sektor primer dapat dilihat melalui peta tematik pada Gambar 5.
Provinsi dengan total efek spasial tinggi terdapat di Provinsi Jambi, Kepulauan Riau, Lampung, dan sebagian besar provinsi di Pulau Jawa. Sedangkan provinsi dengan efek yang rendah cenderung berada pada daerah ujung Indonesia seperti Aceh, Papua, dan Kalimantan Utara. Hal ini diakibatkan karena dengan pembobot jarak maka efek spasial yang tinggi terpusat pada daerah yang memiliki akses geografis terdekat. Hal ini juga menunjukkan bahwa tingginya efek spasial berdampak pada pusat perkembangan ekonomi di Indonesia. Salah satu contohnya yaitu Provinsi Jambi yang memiliki efek spasial tinggi di mana nilai produktivitas pekerja setengah menganggur sektor primer di daerah tersebut yang juga tinggi.

Efek spasial dari variabel dependen yang signifikan hanya dimiliki pada sektor primer. Hal ini sesuai dengan penelitian yang dilakukan oleh Olejnik (2014) di mana variabel spasial lag dari produktivitas memiliki pengaruh yang signifikan yang berarti produktivitas daerah tetangga memiliki pengaruh terhadap produktivitas suatu wilayah. Berdasarkan hasil pemodelan persamaan Spatial Durbin pada sektor primer, ditunjukkan bahwa efek spasial dari produktivitas pekerja adalah bernilai negatif. Semakin tinggi produktivitas pekerja di daerah tetangga, maka akan semakin rendah produktivitas pekerja di daerah tersebut. Demikian juga sebaliknya semakin rendah produktivitas pekerja di daerah lain (tetangga) maka produktivitas daerah tersebut semakin meningkat. Fenomena ini diakibatkan karena ketika produktivitas pekerja setengah menganggur sektor primer di daerah lain menurun yang dapat diakibatkan karena berkurangnya lahan, ketidaksesuaian musim atau lain sebagainya maka 
pekerja tersebut cenderung untuk melakukan perpindahan kerja ke daerah lain yang terdekat sehingga dengan penyesuaian kerja di daerah tersebut akan meningkatkan produktivitasnya. Menurut Borjas (2013) peningkatan kedatangan pekerja di suatu daerah akan meningkatkan produktivitas pekerja daerah tersebut akibat dari adanya penyesuaian kerja yang terjadi. Dengan demikian semakin banyak pekerja maka penyesuaian kerja akan semakin meningkat atau bisa mencapai kondisi "right man on a right place". Perpindahan pekerja yang terjadi juga memberikan indikasi bahwa pekerja tersebut menghindari seasonal unemployment atau pengangguran musiman yang sering terjadi pada sektor primer. Perpindahan pekerja ini juga ditunjukkan dari keterikatan pekerja setengah menganggur sektor primer pada suatu daerah yang rendah. Pekerja di sektor primer lebih tidak terikat pada suatu instansi dalam bekerja, sehingga akan lebih mudah untuk melakukan perpindahan kerja atau migrasi pada waktu yang lebih singkat dibanding pekerja pada sektor lainnya. Penurunan produktivitas di suatu daerah akibat dari meningkatnya produktivitas daerah lain memberikan indikasi dari adanya backwash effect. Peningkatan produktivitas pekerja suatu daerah diakibatkan karena daerah tersebut menyerap sumber daya dari daerah yang berada di sekitarnya sehingga akan mengurangi produktivitas daerah tetangga. Sumber daya yang dapat diserap dalam hal ini adalah sumber daya tenaga kerja atau pekerja setengah menganggur. Peningkatan penyerapan tenaga kerja yang terjadi akan meningkatkan produktivitas pekerja daerah tersebut. Pekerja biasanya melakukan perpindahan pekerja pada daerah yang memberikan keuntungan maksimum sehingga daerah yang terdekat akan menjadi pilihan akibat biaya migrasi yang lebih rendah. Hal ini sesuai dengan yang dikatakan Myrdal (1957) mengenai backwash effect, yaitu mengorbankan daerah yang berada di sekitarnya sehingga pertumbuhan di suatu daerah meningkat yang dapat menyebabkan ketimpangan. Backwash effect terjadi tidak hanya akibat perpindahan tenaga kerja, namun juga karena perpindahan modal dari daerah dengan produktivitas pekerja rendah menuju daerah dengan produktivitas pekerja yang tinggi, seperti penelitian yang dilakukan Husni \& Wikarya (2014). Faktor lain yang menjadi indikasi backwash effect adalah adanya keunggulan sektor primer pada suatu daerah sehingga dapat meningkatkan nilai produktivitas pekerjanya, seperti majunya perkebunan kelapa sawit, ditemukannya daerah tambang baru, dan lainnya. Berdasarkan data BPS, Provinsi Riau menjadi daerah dengan produksi kelapa sawit tertinggi di Indonesia tahun
2017. Hal ini menjadi indikasi backwash effect di mana Provinsi Riau tergolong provinsi dengan tingkat produktivitas pekerja setengah menganggur tertinggi di sektor primer (Gambar 6). Hal ini karena terjadinya mobilitas tenaga kerja ataupun modal ke daerah tersebut akibat sektor unggulan perkebunan kelapa sawit yang berkembang.

Variabel UMP juga memiliki pengaruh yang positif terhadap produktivitas pekerja setengah menganggur pada sektor primer. Kenaikan UMP di suatu daerah cenderung akan meningkatkan produktivitas pekerja sektor primer di daerah tersebut. UMP memiliki dampak positif tidak hanya pada pekerja setengah menganggur pada seluruh sektor namun juga secara spesifik di sektor primer. Dampak positif UMP pada sektor primer menunjukkan bahwa kenaikan upah minimum di suatu daerah tidak hanya berimbas pada pekerja perkantoran yang biasanya mendapatkan upah berdasarkan upah minimum. Hal ini juga mengindikasikan bahwa perubahan nilai UMP pada suatu provinsi menggambarkan bagaimana kondisi pekerja di suatu daerah yang ditunjukkan melalui pengaruhnya terhadap produktivitas melalui peningkatan upah yang didapat oleh pekerja setengah menganggur. Dampak secara tidak langsung (spillover effect) dari UMP juga memiliki pengaruh yang signifikan terhadap produktivitas pekerja setengah menganggur di sektor primer. Dengan demikian kenaikan UMP di daerah tetangga akan meningkatkan produktivitas pekerja di suatu daerah. UMP suatu daerah dapat menggambarkan tingkat kemajuan perekonomian di daerah tersebut. Peningkatan UMP yang terjadi pada daerah tetangga akan memicu peningkatan aktivitas ekonomi daerah tersebut dan akan berdampak pada peningkatan ekonomi suatu daerah akibat aktivitas perdagangan yang terjadi sehingga UMP suatu daerah juga akan mengalami kenaikan. Dengan demikian, UMP yang meningkat pada daerah tetangga cenderung akan meningkatkan produktivitas pekerja suatu daerah. Hal ini menunjukkan bahwa apabila terjadi perubahan pada UMP di suatu provinsi maka akan menggerakan provinsi-provinsi di sekitarnya. Namun spillover effect dari UMP hanya terjadi pada pekerja setengah menganggur sektor primer, sehingga hal ini menunjukkan bahwa penetapan UMP suatu daerah akan sangat berdampak pada perkembangan sektor primer daerah tersebut dan daerah sekitarnya.

Tingkat pendidikan di suatu daerah yang digambarkan melalui rata-rata lama sekolah memiliki pengaruh yang positif namun tidak signifikan pada produktivitas pekerja setengah menganggur sektor primer. Tidak signifikannya rata-rata lama sekolah terhadap produktivitas pekerja sektor primer memberikan indikasi bahwa produktivitas pekerja 
sektor primer tidak memerlukan tingkat pendidikan formal yang tinggi namun lebih mengutamakan peningkatan skill dan kemampuan secara praktik melalui pelatihan. Pengaruh secara tidak langsung (spillover effect) dari rata-rata lama sekolah terhadap produktivitas pekerja tidak berpengaruh signifikan pada sektor primer. Dapat juga dikatakan bahwa untuk sektor primer baik efek langsung maupun tidak langsung, tingkat pendidikan yang digambarkan melalui rata-rata lama sekolah tidak memiliki pengaruh yang signifikan terhadap produktivitas pekerja sektor primer. Hal ini menunjukkan bahwa mindset atau pemikiran pekerja dalam sektor primer seperti petani masih berpikir bahwa pendidikan tidak terlalu penting untuk pekerja di sektor primer.

Berdasarkan Model Spasial Durbin yang telah dibentuk ternyata angka harapan hidup memiliki pengaruh yang signifikan dan positif terhadap produktivitas pekerja setengah menganggur di sektor primer. Signifikansi nilai $\mathrm{AHH}$ pada produktivitas pekerja setengah menganggur sektor primer ini sesuai dengan penelitian yang dilakukan oleh Faisal (2013) yang menyatakan bahwa selain variabel pendidikan, tingkat kesehatan pekerja juga memiliki pengaruh yang signifikan terhadap produktivitas pekerja di Kalimantan Barat. Penelitian yang dilakukan oleh Zulhanafi, et al. (2013) juga mengatakan bahwa variabel kesehatan memiliki pengaruh yang signifikan terhadap produktivitas pekerja. Tingkat kesehatan yang digambarkan melalui AHH memiliki dampak positif dan signifikan hanya pada sektor primer, hal ini menunjukkan bahwa tingkat kesehatan lebih memengaruhi produktivitas pekerja setengah menganggur sektor primer dibandingkan seluruh sektor. Selain itu, signifikannya tingkat kesehatan memberikan indikasi bahwa peningkatan kualitas kesehatan lebih memberikan dampak terhadap peningkatan efisiensi ataupun efektifitas pekerja dalam bekerja sehingga produktivitasnya meningkat dibandingkan dengan peningkatan tingkat pendidikan formal. Fenomena ini mungkin diakibatkan karena pada sektor primer, pekerja memerlukan fisik yang lebih kuat akibat dari pekerjaan yang lebih didominasi pada pekerjaan kasar. Apabila dilihat pada spillover effect dari AHH maka angka harapan hidup berpengaruh positif dan signifikan pada sektor primer. Dapat dikatakan juga baik secara langsung maupun tidak langsung angka harapan hidup merupakan variabel penting yang memiliki pengaruh positif dan signifikan terhadap produktivitas pekerja setengah menganggur di sektor primer. Adanya spillover effect pada angka harapan hidup menunjukkan bahwa peningkatan $\mathrm{AHH}$ di daerah lainnya (tetangga) akan meningkatkan produktivitas pekerja di suatu daerah. Hasil ini memberikan indikasi bahwa adanya indikasi pengelompokan nilai $\mathrm{AHH}$ antarprovinsi di Indonesia. Daerah dengan nilai $\mathrm{AHH}$ yang mirip cenderung mengalami pengelompokkan seperti yang ditunjukkan pada Gambar 3d. Dengan demikian suatu daerah yang memiliki tingkat kesehatan yang baik maka akan berpengaruh pada lingkungan sekitarnya atau daerah tetangganya sehingga dapat meningkatkan produktivitas pekerja setengah menganggur daerah tetangga tersebut. Demikian pula apabila kualitas kesehatan suatu daerah tidak baik atau nilai angka harapan hidupnya rendah maka kualitas kesehatan daerah tetangganya juga akan rendah sehingga produktivitas pekerja setengah menganggur daerah tetangganya menjadi menurun. Hasil ini sesuai dengan penelitian yang dilakukan oleh Tanzir \& Utomo (2015) mengenai efek spasial dari tingkat kesehatan yang digambarkan melalui angka morbiditas.

Persentase belanja modal memiliki peran yang penting pada sektor primer yaitu memiliki pengaruh yang positif dan signifikan terhadap produktivitas pekerja setengah menganggur. Signifikansi variabel persentase belanja modal pada sektor primer menunjukkanbahwaprosespembangunan di Indonesia juga berpengaruh terhadap perkembangan sektor primer di mana pengaruhnya terhadap peningkatan produktivitas pekerja setengah menganggur. Hal ini juga menunjukkan bahwa meskipun kondisi Indonesia dalam proses perubahan menuju negara maju dengan adanya transisi sektor ekonomi menuju sektor sekunder dan tersier, namun sektor primer sebagai dasar penunjang sektor lainnya juga tidak bisa serta merta ditinggalkan. Persentase belanja modal menjadi semakin penting dalam menunjang pembangunan karena tidak hanya efek langsung yang dimiliki namun juga spillover effect yang ada dalam meningkatkan produktivitas pekerja setengah menganggur di sektor primer. Nilai positif dari spillover effect terhadap produktivitas pekerja setengah menganggur sektor primer menunjukkan bahwa terjadinya konsentrasi investasi yang ditunjukkan dari pengelompokkan persentase belanja modal tidak berdampak pada penurunan keseimbangan produktivitas pekerja. Persentase belanja modal memberikan spread effect pada daerah sekitarnya di mana dengan semakin meningkatnya persentase belanja modal maka akan semakin menambah persediaan modal daerah itu sendiri dan daerah tetangganya yang akan meningkatkan produktivitas pekerjanya.

Apabila dilakukan perbandingan antara produktivitas pekerja setengah menganggur di seluruh sektor dan pekerja setengah menganggur di sektor primer maka dapat dilihat salah satu karakteristik yang menonjol. Produktivitas pekerja 
setengah menganggur di sektor primer salah satunya dipengaruhi oleh variabel kesehatan, yaitu angka harapan hidup dan variabel pendidikan tidak signifikan. Pada produktivitas pekerja setengah menganggur seluruh sektor salah satunya dipengaruhi oleh tingkat penddikan sedangkan tingkat kesehatan tidak signifikan memengaruhi. Berdasarkan signifikansi dari spillover effect juga menunjukkan bahwa pekerja setengah menganggur di sektor primer lebih tidak terikat pada pekerjaan di suatu daerah atau dengan kata lain lebih mudah untuk berpindah kerja ke daerah lain, sedangkan pekerja setengah menganggur seluruh sektor di mana terdapat sektor sekunder dan tersier menunjukkan bahwa pekerjanya lebih terikat pada suatu perusahaan pada waktu yang lebih lama. Hal ini ditunjukkan pada pemodelan spasial, di mana signifikansi dari efek spasial dari variabel yang melekat pada pekerja seperti tingkat kesehatan dan pendidikan tidak signifikan memengaruhi, sedangkan efek spasial yang melekat pada aktor ketiga dalam perekonomian, yaitu pemerintah, seperti persentase belanja modal tetap berpengaruh secara signifikan.

\section{KESIMPULAN}

Berdasarkan hasil analisis dan pembahasan maka dapat ditarik kesimpulan sebagai berikut:

1. Produktivitas pekerja setengah menganggur seluruh sektor tidak menunjukkan adanya pola persebaran yang mengelompok, sedangkan di sektor primer ditunjukkan adanya pola persebaran mengelompok. Sebagian besar nilai produktivitas pekerja setengah menganggur masih rendah. Gambaran umum faktor-faktor yang memengaruhi produktivitas pekerja setengah menganggur, yaitu:

a. Gambaran UMP memiliki persebaran yang searah dengan produktivitas pekerja setengah menganggur di sektor primer. Provinsi dengan upah minimum yang tinggi cenderung memiliki produktivitas yang tinggi.

b. Persebaran persentase belanja modal memiliki indikasi arah hubungan positif terhadap produktivitas pekerja setengah menganggur sektor primer. Provinsi dengan persentase belanja modal yang tinggi cenderung memiliki produktivitas yang tinggi.

c. Persebaran rata-rata lama sekolah (RLS) tidak menunjukkan indikasi hubungan yang tidak konsisten dengan produktivitas pekerja setengah menganggur sektor primer. Sebagian provinsi memiliki arah hubungan yang positif antara RLS dengan produktivitas pekerja sedangkan sebagian lagi memiliki arah hubungan yang negatif.

d. Persebaran angka harapan hidup menunjukkan indikasi arah hubungan yang positif dengan produktivitas pekerja, di mana terdapat indikasi ketimpangan pembangunan kesehatan pada Indonesia bagian timur.

2. Berdasarkan uji Global Moran's I hanya variabel produktivitas pekerja setengah menganggur sektor primer yang memiliki efek spasial. Pada produktivitas pekerja setengah menganggur seluruh sektor, hanya variabel persentase belanja modal yang memiliki efek langsung dan spillover effect. Sedangkan upah minimum dan rata-rata lama sekolah hanya memiliki efek langsung terhadap produktivitas pekerja setengah menganggur. Pada sektor primer upah minimum, angka harapan hidup serta persentase belanja modal memiliki efek langsung dan spillover effect terhadap produktivitas pekerja. Demikian pula untuk efek spasial dari produktivitas pekerja sektor primer daerah tetangga memiliki pengaruh yang berarti terhadap produktivitas pekerja di suatu daerah.

3. Kelemahan pada penelitian ini yaitu variabel independen yang digunakan untuk menggambarkan produktivitas pekerja setengah menganggur tidak spesifik dibangun khusus untuk sektor primer. Dengan demikian untuk penelitian selanjutnya disarankan untuk menggunakan variabel independen yang khusus dibangun untuk sektor primer.

\section{DAFTAR PUSTAKA}

\section{Buku}

Anselin, L. (2005). Exploring spatial data with GeoDa: A workbook. Urbana: University of Illinois.

Anselin, L. (1988). Spatial econometrics: Methods and models. Netherlands: Kluwer Academic Publisher.

Badan Pusat Statistik. (2017a). Indeks Pembangunan Manusia 2017. Jakarta: Badan Pusat Statistik.

Badan Pusat Statistik. (2017b). Keadaan angkatan kerja di Indonesia Agustus 2017. Jakarta: Badan Pusat Statistik.

Badan Pusat Statistik. (2017c). Potret pendidikan Indonesia statistik pendidikan 2017. Jakarta: Badan Pusat Statistik. 
Badan Pusat Statistik. (2017d). Publikasi statistik keuangan pemerintah. Jakarta: Badan Pusat Statistik.

Badan Pusat Statistik. (2011). Analisis dampak spasial pada peramalan perekonomian dan ketenagakerjaan provinsi. Jakarta: Badan Pusat Statistik.

Borjas, G.J. (2013). Labor economics. New York: Mc Graw-Hill.

Lesage, J. \& Pace, R.K. (2009). Introduction to spatial econometrics. Boca Raton: CRC Press.

Maynard, D.C., \& Feldman, D.C. (2011). Underemployment: Psychological, economic and social challenges. New York: Springer.

Myrdal, G. (1957). Economic theory and underdeveloped regions. London: Duckworth.

Mutis, T., \& Gaspersz, V. (2004). Nuansa menuju perbaikan kualitas dan produktivitas. Jakarta Barat: Universitas Trisakti.

Pristyadi, B., \& Sukaris. (2017). Pengantar teori ekonomi mikro pendekatan teoritis praktis. Sidoarjo: Indomedia Pustaka.

Sicat, G.P., \& Arndt, H.W. (1991). Ilmu ekonomi, Untuk konteks Indonesia. Jakarta: LP3ES.

Sukirno, S. (2004). Pengantar teori mikroekonomi, Edisi Ketiga. Jakarta: PT RajaGrafindo Persada.

Todaro, M.P. (2000). Pembangunan ekonomi di dunia ketiga. Jakarta: Erlangga.

\section{Jurnal dan Working Paper}

Ariani, Ni W.D., \& Suresmiathi, D.A.A. Ayu. (2013). Pengaruh kualitas tenaga kerja, bantuan modal usaha dan teknologi terhadap produktivitas kerja Usaha Mikro Kecil dan Menengah (UMKM) di Jimbaran. E-Jurnal EP Unud, 2(2), 102-107.

Elhorst, J.P., \& Vega, S.H. (2017). The SLX Model: Extensions and the sensitivity of spatial spillover to W. Papeles de Economia Española,152, 34-50.

Fitri, I., Syofyan, E., \& Aimon, H. (2015). Analisis faktorfaktor yang mempengaruhi produktivitas tenaga kerja dan pertumbuhan ekonomi di Sumatera Barat. Jurnal Kajian Ekonomi, 4(7), 1-14.

Kinanti, C.S. (2015). Analisis tentang setengah penganggur di Indonesia: Antara sukarela dan keterpaksaan. Jurnal Ilmiah Mahasiswa FEB Universitas Brawijaya, 3(1), 1-20.
Olejnik, A. (2014). An empirical study of productivity growth in EU28-spatial panel analysis. Comparative Economic Research, 17(4), 187-202.

Sitorus, Y.M., \& Yuliana, L. (2018). Penerapan regresi data panel pada analisis pengaruh infrastruktur terhadap produktivitas ekonomi provinsiprovinsi di luar Pulau Jawa tahun 2010-2014. Jurnal Media Statistika, 11(1), 1-15.

Zulhanafi, H.A., \& Syofyan, E. (2013). Analisis faktorfaktor yang mempengaruhi produktivitas dan tingkat pengangguran di Indonesia. Jurnal Kajian Ekonomi, 2(3), 85-109.

\section{Skripsi dan Tesis}

Azhara, T. (2014). Analisis konvergensi produktivitas tenaga kerja antarprovinsi di Indonesia. Skripsi. Bogor: Institut Pertanian Bogor.

Faisal, H. (2013). Pengaruh tingkat pendidikan, kesehatan terhadap produktivitas dan jumlah penduduk miskin di Provinsi Kalimantan Barat. Tesis. Pontianak: Universitas Tanjung Pura.

Fatchurrohman, T.A. (2014). Analisis spasial disparitas produktivitas tenaga kerja, Studi kasus 38 kabupaten/kota di Jawa Timur. Skripsi. Malang: Universitas Brawijaya.

Husni, G.G., \& Wikarya, U. (2014). Analisis spillover effect pada kegiatan ekonomi sektoral dalam koridor ekonomi Kalimantan. Skripsi. Depok: Universitas Indonesia.

Kasmita, N. (2014). Pengaruh jam kerja pengalaman kerja dan pendidikan terhadap pendapatan karyawan PT. Socfindoseumanyam Kabupaten Nagan Raya. Skripsi. Aceh Barat: Universitas Teuku Umar.

Pasaribu, E. (2015). Dampak spillover dan multipolaritas perkembangan wilayah pusat-pusat pertumbuhan di Kalimantan. Tesis. Bogor: Institut Pertanian Bogor.

Priyanto, W. (2014). Analisis faktor-faktor yang memengaruhi produktivitas kerja karyawan (Studi kasus pada bagian distribusi perusahaan daerah air minum PDAM Kabupaten Banyuwangi). Skripsi. Malang: Universitas Brawijaya.

Tanzir, M., \& Utomo, A.P. (2015). Analisis spasial morbiditas di Provinsi Jawa Tengah tahun 2015. Skripsi. Jakarta: Sekolah Tinggi Ilmu Statistik. 


\section{LAMPIRAN}

Lampiran 1. Ringkasan Pengujian Asumsi Klasik dan Likelihood Ratio pada Model Regresi Spasial

Tabel 1. Produktivitas Pekerja Setengah Menganggur (SLX)

\begin{tabular}{lccc}
\hline \multicolumn{1}{c}{ Jenis Pengujian } & Nilai Statistik Uji & P-Value & Keputusan \\
\hline (1) & $(2)$ & $(3)$ & $(4)$ \\
\hline Homoskedastisitas & 7,417 & 0,492 & Gagal Tolak $\mathrm{H}_{0}$ \\
\hline Normalitas & 0,425 & 0,809 & Gagal Tolak $\mathrm{H}_{0}$ \\
\hline Non-Autokorelasii & 0,493 & 0,382 & Gagal Tolak $\mathrm{H}_{0}$ \\
\hline Likelihood Ratio & $-8,366$ & 0,080 & Tolak $\mathrm{H}_{0}$ \\
\hline
\end{tabular}

Tabel 2. Produktivitas Pekerja Setengah Menganggur Sektor Primer (SDM)

\begin{tabular}{cccc}
\hline \multicolumn{1}{c}{ Jenis Pengujian } & Nilai Statistik Uji & $\boldsymbol{P}$-Value & Keputusan \\
\hline (1) & $(2)$ & $(3)$ & $(4)$ \\
\hline Homoskedastisitas & 9,621 & 0,293 & Gagal Tolak $\mathrm{H}_{0}$ \\
\hline Normalitas & 5,276 & 0,072 & Gagal Tolak $\mathrm{H}_{0}$ \\
\hline
\end{tabular}

Lampiran 2. Nilai VIF atau Variance Inflation Factor Variabel Independen

\begin{tabular}{ccccc}
\hline Variabel & Ln(UMP) & RLS & AHH & Persentase Belanja Modal \\
\hline$(1)$ & $(2)$ & $(3)$ & $(4)$ & $(5)$ \\
\hline VIF & 1,281 & 1,379 & 1,257 & 1,103 \\
\hline
\end{tabular}


HALAMAN INI SENGAJA DIKOSONGKAN 